Article

\title{
Ceria-Zirconia Mixed Metal Oxides Prepared via Mechanochemical Grinding of Carbonates for the Total Oxidation of Propane and Naphthalene
}

\author{
Parag M. Shah, Joseph W. H. Burnett, David J. Morgan ${ }^{\circledR}$, Thomas E. Davies and \\ Stuart H. Taylor *(D) \\ Cardiff Catalysis Institute, School of Chemistry, Cardiff University, Main Building, Park Place, Cardiff CF10 3AT, \\ UK; shahp26@cardiff.ac.uk (P.M.S.); r01jwb17@abdn.ac.uk (J.W.H.B.); MorganDJ3@cardiff.ac.uk (D.J.M.); \\ DaviesTS@cardiff.ac.uk (T.E.D.) \\ * Correspondence: taylorsh@cardiff.ac.uk; Tel.: +44-(0)29-2087-4062
}

Received: 30 April 2019; Accepted: 20 May 2019; Published: 22 May 2019

check for updates

\begin{abstract}
A series of ceria-zirconia mixed metal oxides with varying metal ratios were prepared by the calcination of precursors synthesized by mechanochemical grinding of the metal carbonates, and tested for catalytic naphthalene and propane total combustion. The mechanically-mixed metal oxides were more active for both propane and naphthalene total oxidation compared to the parent metal oxides. $\mathrm{Ce}_{0.95} \mathrm{Zr}_{0.05} \mathrm{O}_{\mathrm{x}}$ was the most active catalyst for the total combustion of propane and naphthalene. Catalysts were characterized by x-ray diffraction, BET surface area, laser Raman spectroscopy, temperature programmed reduction, scanning electron microscopy with energy dispersive x-ray analysis and $\mathrm{x}$-ray photoelectron spectroscopy techniques. Formation of ceria-zirconia solid solutions was observed for catalysts with a zirconia content of $10 \%$ or lower, whereas ceria and zirconia phase separation was observed when zirconia content was above $25 \%$. Surface area increased when ceria and zirconia were mixed, and the reduction temperature of the bulk shifted to lower temperatures upon increasing zirconia content. Incorporation of zirconia was found to increase the relative concentration of surface oxygen defects compared to pure ceria, with low amounts of zirconia showing the greatest increase. The concentration of oxygen defects correlates with propane and naphthalene total oxidation activity. The enhanced total oxidation activity occurs as a result of the increased number of oxygen defects and the higher surface area. The results demonstrate that mechanochemical preparation from carbonate precursors was an effective route to make active catalysts.
\end{abstract}

Keywords: ceria; zirconia; VOC; catalytic oxidation; propane; naphthalene

\section{Introduction}

Aromatic and short chain hydrocarbons form part of a broad range of atmospheric pollutants called volatile organic compounds (VOCs). These potent greenhouse gases are responsible for an array of environmental problems. They are responsible for the formation of ground level ozone $[1,2]$ and some can agglomerate and condense, forming particulates [3,4]. Therefore, it is essential to reduce, and if possible, eliminate the emission of VOCs. Two model VOCs that are appropriate to study are propane and naphthalene.

Recently there has been an increase in the use of liquefied petroleum gas (LPG), which is a mixture of propane and other short chain hydrocarbons, as a transport fuel. Over 2.4 million barrels of LPG were used daily in the USA in 2012, rising to over 4 million in 2014 [5]. This trend has also been observed across the world. This is due to the cleaner combustion of LPG and increased cost efficiency compared to traditional fuels [6,7]. Propane is also used by many industries, and the increased use has resulted in an increase in atmospheric propane emissions [7]. 
Naphthalene is the simplest poly-aromatic hydrocarbon (PAH) within the family of VOCs and has been identified as being particularly hazardous to health. Naphthalene is emitted during the production of coal tar or the combustion of diesel and a wide variety of organic materials [8]. It is a known carcinogen, and accordingly it is also essential that its release into the atmosphere is reduced, and if possible, eliminated.

Thermal oxidation, adsorption, absorption, and catalytic oxidation are all used to control the emission of VOCs into the atmosphere. Each of these methods has its strengths and its limitations. Catalytic oxidation is recognized as one of the most efficient and flexible methods, due to its ability to remove pollutants to very low levels, and destroy VOCs with high selectivity to carbon dioxide and water.

Catalytic total oxidation also has the ability to remove a range of different VOCs from a single effluent stream [9]. Supported noble metals currently make up $75 \%$ of all VOC total oxidation catalysts [10], but are prone to deactivation under certain conditions; metal oxide catalysts would provide an alternative were they to have sufficient activity. Ceria has been proposed as a suitable replacement due to its ability to form non-stoichiometric $\mathrm{CeO}_{2-x}$, with the resulting surface defect sites leading to oxygen vacancies forming active surface oxygen species [11,12]. The same effect has also been observed with zirconia [13] and when both metal oxides are combined together the effect is enhanced. This is due to the zirconia increasing the mobility of lattice oxygen species due to an increase in the reducibility of $\mathrm{Ce}^{4+}$ to $\mathrm{Ce}^{3+}[14,15]$. The mobility of surface oxygen is also increased, as is the thermal resistance of the mixed metal oxide, making these catalysts excellent candidates for VOC total oxidation [15].

Ceria-zirconia mixed oxide catalysts have been tested for naphthalene $[16,17]$ total oxidation, as well as for the combustion of a number of other VOCs, including methane [18] and soot [19]. There is, however, very little literature on the total oxidation of propane over ceria-zirconia mixed metal oxide catalysts. Palladium and platinum nanoparticles supported on ceria-zirconia were reported to be active for propane total oxidation [10,11]. In all studies, ceria-zirconia mixed oxides were reported to be more active than the individual metal oxide components. Overall, ceria-zirconia with low concentrations of zirconia were reported to be the most active catalysts.

The method of catalyst preparation can strongly influence catalyst performance, and can also have an impact on the environment. Typical methods of mixed metal oxide catalyst preparation, such as co-precipitation or sol-gel, can produce significant quantities of aqueous waste. An alternative is mechanochemical preparation, as it is a relatively simple process with no waste solvents produced; one of the central ideas of green chemistry is the prevention of waste during and after synthesis [20]. Another advantage of mechanochemical grinding is the reduction of potential surface poisons, as precipitating agents like sodium or potassium carbonate are avoided. Materials prepared mechanochemically have been reported to show increased oxygen storage capacity and surface area [21]. Ceria-zirconia mixed metal oxides prepared via mechanochemical grinding also show good mixing of the two components, however, their efficacy as catalysts for VOC oxidation has not been established [22-24].

Recently, we established that ceria-zirconia prepared from the calcination of a catalyst precursor, synthesized by mechanochemical grinding of cerium and zirconium nitrates, formed active catalysts for the total oxidation of naphthalene and propane [25]. The ratio of cerium to zirconia, along with the intimate mixing of the components, were important factors controlling catalyst activity. In this study we have expanded on our initial work, investigating the preparation of ceria-zirconia by mechanochemical grinding of carbonate precursors, to see if this method is a more generic approach to prepare active VOC oxidation catalysts. We studied catalyst activity for the total combustion of propane and naphthalene, as contrasting VOCs, and the influence of zirconia content. The catalyst surface and bulk structure have been characterized, and key catalyst features relating to performance have been established. 


\section{Results and Discussion}

\subsection{Catalyst Performance}

The catalytic activity of ceria-zirconia mixed metal oxide catalysts for the total oxidation of propane is shown in Figure 1. Only 6\% of the propane was converted at $600{ }^{\circ} \mathrm{C}$ in an empty reactor, indicating that contribution from gas phase homogeneous reactions was negligible. All catalysts demonstrated appreciable propane total oxidation activity, with a high selectivity to $\mathrm{CO}_{2}(>99 \%)$. The ceria showed $100 \%$ propane conversion at $600{ }^{\circ} \mathrm{C}$, whereas zirconia did not reach total conversion. The higher activity noted for the ceria compared to the zirconia can be attributed to the enhanced ability of ceria to activate $\mathrm{C}-\mathrm{H}$ bonds as compared to zirconia [26]. Only one ceria-zirconia mixed metal oxide had lower propane total oxidation activity than the ceria, the $\mathrm{Ce}_{0.50} \mathrm{Zr}_{0.50} \mathrm{O}_{\mathrm{x}}$, and the order of catalytic activity was:

$$
\mathrm{Ce}_{0.95} \mathrm{Zr}_{0.05} \mathrm{O}_{\mathrm{x}}>\mathrm{Ce}_{0.90} \mathrm{Zr}_{0.10} \mathrm{O}_{\mathrm{x}}>\mathrm{Ce}_{0.75} \mathrm{Zr}_{0.25} \mathrm{O}_{\mathrm{x}}>\mathrm{CeO}_{2}>\mathrm{Ce}_{0.50} \mathrm{Zr}_{0.50} \mathrm{O}_{\mathrm{x}}>\mathrm{ZrO}_{2} .
$$

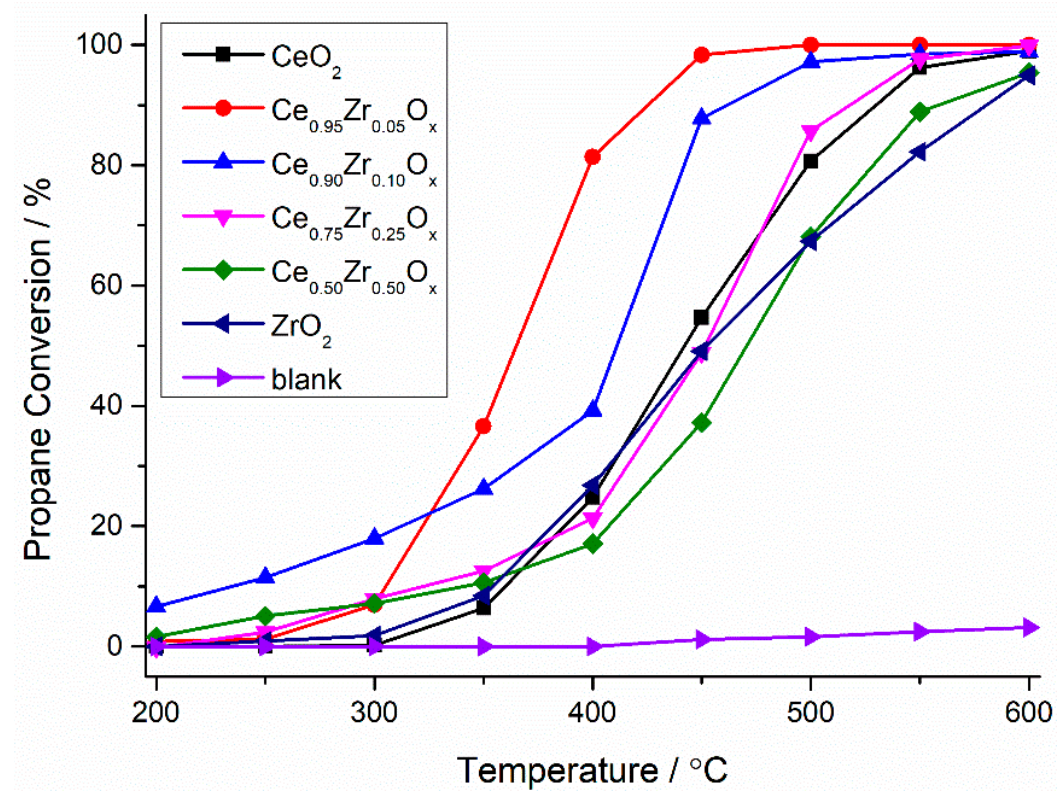

Figure 1. Catalytic activity for the total oxidation of propane over the ceria-zirconia mixed metal oxide catalysts prepared using carbonate precursors. Reaction conditions: GHSV $=45,000 \mathrm{~h}^{-1}, 5000 \mathrm{ppm}$ propane in air. Legend refers to Ce:Zr ratios.

The catalytic performance of naphthalene total oxidation over the ceria-zirconia mixed metal oxides is shown in Figure 2. A blank reaction showed that no significant homogenous gas phase total oxidation of naphthalene occurred. The zirconia had no activity over the temperature range, and this was also observed in zirconia prepared by urea and sodium carbonate precipitation methods [16]. Ceria could not convert all the naphthalene into $\mathrm{CO}_{2}$ within the temperature range. However, when zirconia was added to the ceria lattice, there was a significant increase in naphthalene total oxidation activity. All ceria-zirconia mixed metal oxides had increased activity compared to their parent single metal oxides, the trend of activity was:

$$
\mathrm{Ce}_{0.95} \mathrm{Zr}_{0.05} \mathrm{O}_{\mathrm{x}}>\mathrm{Ce}_{0.90} \mathrm{Zr}_{0.10} \mathrm{O}_{\mathrm{x}}>\mathrm{Ce}_{0.75} \mathrm{Zr}_{0.25} \mathrm{O}_{\mathrm{x}}>\mathrm{Ce}_{0.50} \mathrm{Zr}_{0.50} \mathrm{O}_{\mathrm{x}}>\mathrm{CeO}_{2}>\mathrm{ZrO}_{2} \text {. }
$$




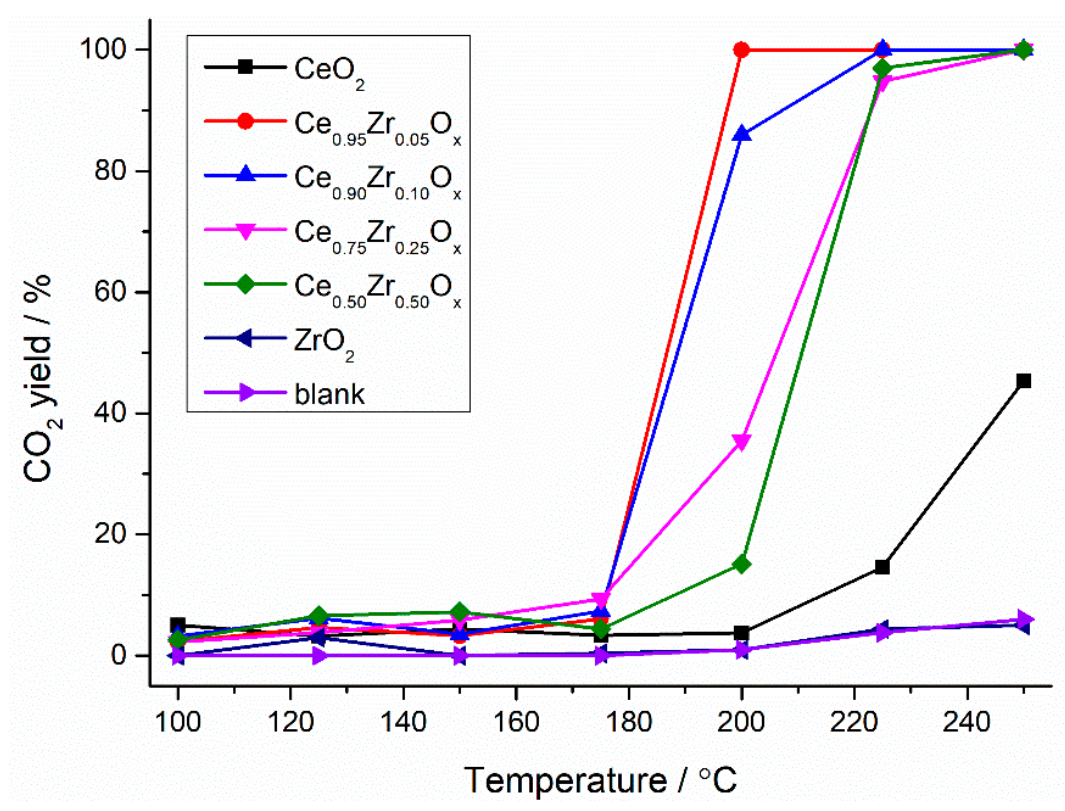

Figure 2. Catalytic activity for the total oxidation of naphthalene for the ceria-zirconia mixed metal oxide catalysts prepared using carbonate precursors. Reaction conditions: GHSV $=45,000 \mathrm{~h}^{-1}$, 100 vppm naphthalene in $20 \% \mathrm{O}_{2}$ balanced with He. Legend refers to different Ce:Zr ratios.

\subsection{Catalyst Characterisation}

The catalyst powder x-ray diffraction (XRD) patterns, and further derived data, are shown in Figure 3 and Table 1 respectively. The XRD pattern of the ceria shows four major peaks at $28^{\circ}, 33^{\circ}, 49^{\circ}$, and $57^{\circ}$, corresponding to the respective (111), (200), (220), and (311) lattice planes of cubic fluorite $\mathrm{CeO}_{2}$ [27]. The XRD pattern of the zirconia showed low intensity peaks at $30^{\circ}, 34^{\circ}, 51^{\circ}$, and $59^{\circ}$, indicating that the zirconia has low crystallinity and is present in the tetragonal phase [28]. However, due to the weak intensity and broad nature of the peaks, it is difficult to analyze if other zirconia phases are present.

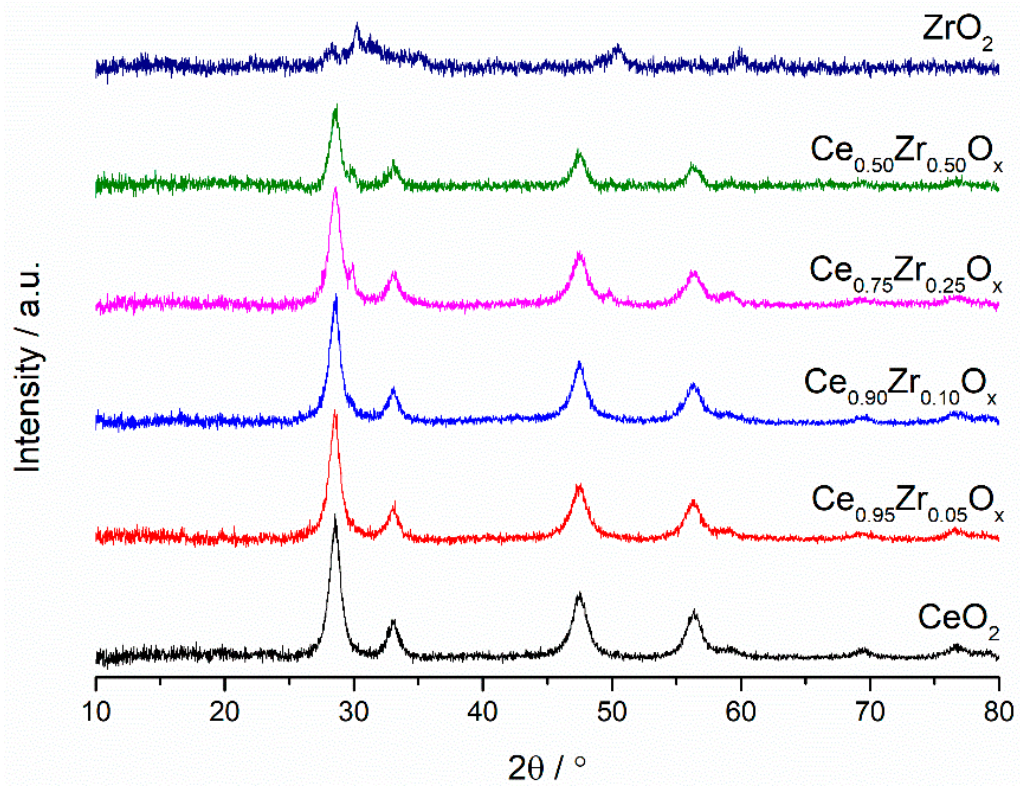

Figure 3. Powder XRD patterns of the ceria-zirconia mixed metal oxide catalysts prepared from carbonate precursors. 
Analysis of the ceria-zirconia mixed metal oxides showed four dominant diffraction peaks assigned to the ceria cubic fluorite structure. The intensity of the peaks decreased as the zirconia content increased. There was also a shift in the position of the diffraction peaks (e.g., data for (111), shown in Table 1), upon increasing the zirconia content. This indicates modification of the ceria lattice parameter by zirconia incorporation $[16,29]$. When the zirconia content of the mixed metal oxide was above $25 \%$, a shoulder peak at $30^{\circ}$ was observed, denoting the presence of bulk tetragonal zirconia, confirming the formation of phase-separated ceria and zirconia. Consequently, single ceria-zirconia solid solution phases were only observed at lower zirconia concentrations. It was previously noted that the simultaneous presence of bulk zirconia in ceria-zirconia mixed metal oxides leads to less active naphthalene total oxidation catalysts [16]. Consequently, the decrease in naphthalene total oxidation activity of the ceria-zirconia catalysts prepared mechanochemically from carbonates upon increasing zirconia content may be due to the poorer mixing of components and more phase segregation.

The Scherrer equation was used to calculate the average crystallite size from the XRD patterns. The four dominant peaks in each pattern were analyzed. The ceria had the largest crystallite size, and zirconia the smallest. The addition of zirconia to ceria resulted in a decrease in crystallite size, with all mixed metal oxides showing crystallite sizes smaller than ceria-this has been observed for other ceria-zirconia catalysts [14]. However, the crystallite size for mixed component catalysts begins to increase for $\mathrm{Ce}_{0.50} \mathrm{Zr}_{0.50} \mathrm{O}_{x}$, suggesting the phase separation is causing crystallite size growth.

Along with decreasing crystallite size, the lattice parameter and unit cell decrease upon the addition of zirconia into the ceria lattice. The contraction of the ceria lattice parameter is expected, due to the smaller ionic radius of the zirconium compared to cerium [30]. The contraction of the lattice parameter on zirconium incorporation into the cubic fluorite ceria lattice is well known [31,32]. The incorporation of zirconium into the ceria lattice will also result in the formation of defect sites, leading to the displacement of oxygen atoms, forming oxygen vacancies, and causing the cerium and zirconium to be displaced also [33]. To consolidate the displacement of lattice atoms, the lattice structure will compress, causing the decrease in unit cell that is observed.

Table 1. Crystallographic properties of the ceria-zirconia mixed metal oxide catalysts calculated from powder XRD data.

\begin{tabular}{|c|c|c|c|c|c|}
\hline Sample & Phases Present & $\begin{array}{l}\text { Position of Ceria } \\
\text { (111) Reflection/ }{ }^{\circ}\end{array}$ & $\begin{array}{c}\text { Average Crystallite } \\
\text { Size/§̊ }\end{array}$ & $\begin{array}{c}\text { Lattice } \\
\text { Parameter/Å }\end{array}$ & $\begin{array}{c}\text { Unit Cell } \\
\text { Volume/ } \AA^{3}\end{array}$ \\
\hline $\mathrm{CeO}_{2}$ & $\mathrm{CeO}_{2}$ & 28.5 & 78 & 5.450 & 161.879 \\
\hline $\mathrm{Ce}_{0.95} \mathrm{Zr}_{0.05} \mathrm{O}_{\mathrm{x}}$ & $\mathrm{CeO}_{2}$ & 28.6 & 73 & 5.422 & 159.396 \\
\hline $\mathrm{Ce}_{0.90} \mathrm{Zr}_{0.10} \mathrm{O}_{\mathrm{x}}$ & $\mathrm{CeO}_{2}$ & 28.7 & 58 & 5.366 & 154.508 \\
\hline $\mathrm{Ce}_{0.75} \mathrm{Zr}_{0.25} \mathrm{O}_{\mathrm{x}}$ & $\mathrm{CeO}_{2}, \mathrm{ZrO}_{2}$ & 28.9 & 56 & 5.266 & 146.030 \\
\hline $\mathrm{Ce}_{0.50} \mathrm{Zr}_{0.50} \mathrm{O}_{\mathrm{x}}$ & $\mathrm{CeO}_{2}, \mathrm{ZrO}_{2}$ & 28.9 & 65 & 5.236 & 143.651 \\
\hline $\mathrm{ZrO}_{2}$ & $\mathrm{ZrO}_{2}$ & - & 43 & $5.100^{+}$ & 132.651 \\
\hline
\end{tabular}

${ }^{\dagger}$ Data from [34].

Table 2 shows a summary of the characterization data for the ceria-zirconia mixed metal oxide catalysts. The ceria and zirconia have the lowest surface area of the range of catalysts. Once any amount of zirconia is added to the ceria, the surface area increases by about $20 \%$ compared to the pure metal oxide samples. This trend has also been observed in previous studies [35,36], with the increase assigned to the smaller crystallite size of ceria-mixed metal oxides compared to the ceria [37]. Higher surface area was noted to be a factor for more active ceria catalysts for VOC total oxidation [38]. Surface normalized rates of propane total oxidation are shown in Table 2. There is no simple relationship between surface area and reaction rates, suggesting that other factors beyond just surface area also influence catalyst performance.

The ceria-zirconia catalysts were characterized using laser Raman spectroscopy (Figure 4). Only one Raman mode, centered at $464 \mathrm{~cm}^{-1}$, was observed for the ceria, which is characteristic of the cubic fluorite phase $\left(\mathrm{F}_{2 \mathrm{~g}}\right)$ [27]. The zirconia had five weak Raman active modes centered at $247 \mathrm{~cm}^{-1}$, 
$307 \mathrm{~cm}^{-1}, 464 \mathrm{~cm}^{-1}, 596 \mathrm{~cm}^{-1}$, and $626 \mathrm{~cm}^{-1}$, which are characteristic of the tetragonal zirconia phase $\left(\mathrm{A}_{1 \mathrm{~g}}+3 \mathrm{E}_{\mathrm{e}}+\mathrm{B} 1_{\mathrm{g}}\right)$. This confirms the XRD analysis, in which only one phase was observed for both single metal oxides.

Table 2. Physiochemical properties of the range of ceria-zirconia catalysts.

\begin{tabular}{|c|c|c|c|c|c|}
\hline Sample & $\begin{array}{l}\text { BET Surface } \\
\text { Area } / \mathrm{m}^{2} \mathrm{~g}^{-1}\end{array}$ & $\begin{array}{c}\text { Surface Area } \\
\text { Normalized Propane } \\
\text { Total Oxidation } \\
\left(\times 10^{-8}\right) / \mathrm{mol} \mathrm{s}^{-1} \mathrm{~m}^{-2} \mathrm{~g}^{-1}\end{array}$ & $\begin{array}{c}\text { Raman Full } \\
\text { Width Half } \\
\text { Maximum } / \mathrm{cm}^{-1}\end{array}$ & 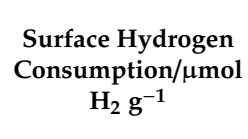 & $\begin{array}{c}\text { Surface Area } \\
\text { Normalized Hydrogen } \\
\text { Consumption } / \mu \mathrm{mol} \mathrm{H}_{2} \\
\mathrm{~m}^{-2}\end{array}$ \\
\hline $\mathrm{CeO}_{2}$ & 62 & 0.36 & 30.9 & 2.28 & 1.23 \\
\hline $\mathrm{Ce}_{0.95} \mathrm{Zr}_{0.05} \mathrm{O}_{\mathrm{x}}$ & 77 & 1.65 & 33.9 & 2.35 & 1.02 \\
\hline $\mathrm{Ce}_{0.90} \mathrm{Zr}_{0.10} \mathrm{O}_{\mathrm{x}}$ & 79 & 1.15 & 38.8 & 2.71 & 1.14 \\
\hline $\mathrm{Ce}_{0.75} \mathrm{Zr}_{0.25} \mathrm{O}_{\mathrm{x}}$ & 75 & 0.58 & 39.4 & 2.73 & 1.21 \\
\hline $\mathrm{Ce}_{0.50} \mathrm{Zr}_{0.50} \mathrm{O}_{\mathrm{x}}$ & 71 & 0.52 & 40.1 & 2.74 & 1.29 \\
\hline $\mathrm{ZrO}_{2}$ & 58 & 0.00 & - & 1.25 & - \\
\hline
\end{tabular}

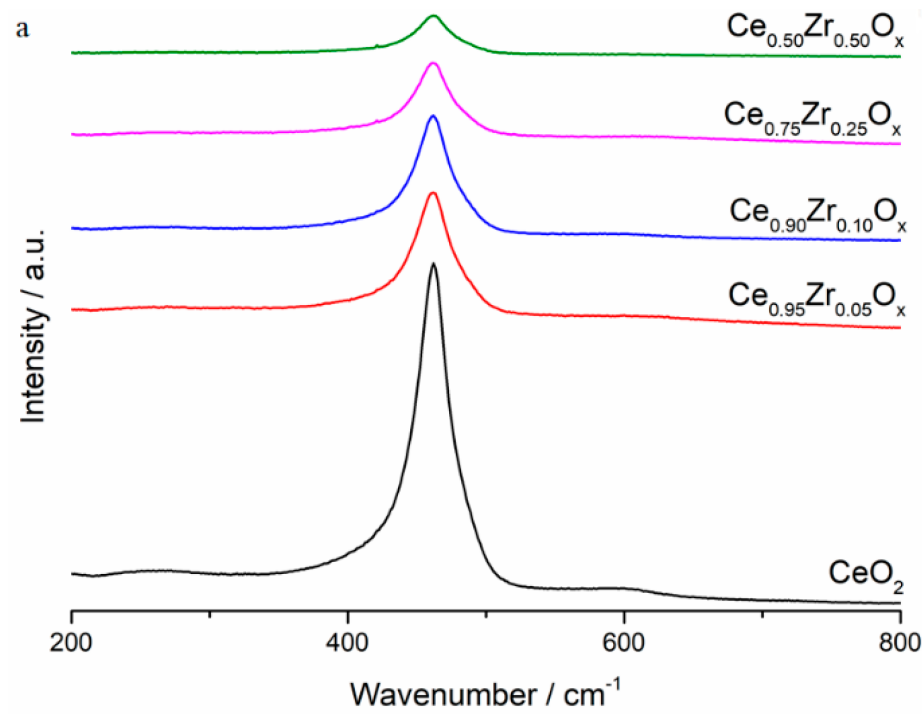

b

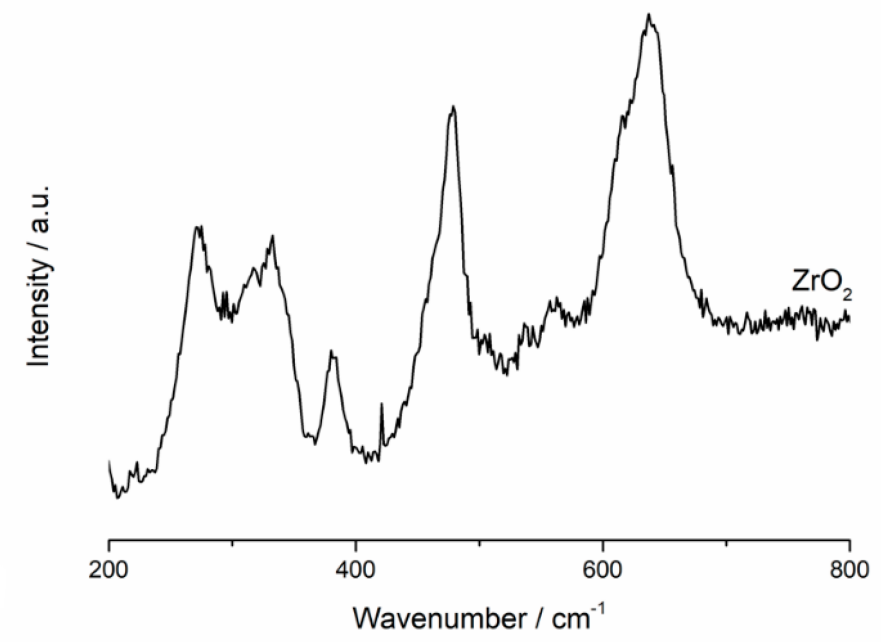

Figure 4. Laser Raman spectra for the (a) $\mathrm{CeO}_{2}, \mathrm{Ce}_{0.95} \mathrm{Zr}_{0.05} \mathrm{O}_{\mathrm{x}}, \mathrm{Ce}_{0.90} \mathrm{Zr}_{0.10} \mathrm{O}_{\mathrm{x}}, \mathrm{Ce}_{0.75} \mathrm{Zr}_{0.25} \mathrm{O}_{\mathrm{x}}$, and $\mathrm{Ce}_{0.50} \mathrm{Zr}_{0.50} \mathrm{O}_{\mathrm{x}}$, and (b) $\mathrm{ZrO}_{2}$ spectra (enhanced $10 \times$ ), prepared from carbonate precursors.

All the ceria-zirconia catalysts had only one Raman band centered at $464 \mathrm{~cm}^{-1}$, confirming the findings from XRD, in which the cubic fluorite ceria phase was prominent. The intensity of the ceria band decreased upon the increase in zirconia content, and this was accompanied by an increase in the 
full width half maximum (FWHM) (Table 2). The ceria had the smallest FWHM, and it increased upon the increase in zirconia content, with the $\mathrm{Ce}_{0.50} \mathrm{Zr}_{0.50} \mathrm{O}_{\mathrm{x}}$ having the largest FWHM. The increase in FWHM can be assigned to a range of factors, including reduction in crystallite size [39] and increased oxygen vacancies [40]. With the crystallite sizes decreasing upon the addition of zirconia into the ceria, this will certainly affect the FWHM, causing it to increase. However, zirconia substitution will also form oxygen vacancies, and these will also increase the FWHM. The increase in oxygen vacancies will lead to more active oxygen species being present on the surface of the catalysts, and this will be an important descriptor for catalyst activity.

Reduction profiles of the ceria-zirconia mixed metal oxides are shown in Figure 5. The ceria had two reduction regions, one at approximately $500{ }^{\circ} \mathrm{C}$ and the second at $800{ }^{\circ} \mathrm{C}$, which attributed to surface reduction and bulk reduction, respectively. Two peaks were noted for surface reduction of the ceria, suggesting that $\mathrm{Ce}^{3+}$ and $\mathrm{Ce}^{4+}$ were both present on the surface of the ceria. $\mathrm{As} \mathrm{Ce}^{4+}$ is easier to reduce than $\mathrm{Ce}^{3+}$, the first surface reduction region can be assigned to the $\mathrm{Ce}^{4+}$ and the higher temperature region to $\mathrm{Ce}^{3+}$ [36]. The zirconia had two reduction peaks, at $540{ }^{\circ} \mathrm{C}$ and $735^{\circ} \mathrm{C}$, assigned to the formation of surface hydroxide groups [41], and bulk zirconia reduction [42], respectively.

When zirconia was incorporated into the lattice, the profiles become less well-defined. Two regions of reduction were noted for all the ceria-zirconia catalysts, one between $350{ }^{\circ} \mathrm{C}$ and $550{ }^{\circ} \mathrm{C}$, representing surface reduction, and the other around $730^{\circ} \mathrm{C}$, representing bulk reduction. The surface reduction feature indicates that both $\mathrm{Ce}^{4+}$ and $\mathrm{Ce}^{3+}$ were present on the surface. The reduction behaviour of $\mathrm{Ce}_{0.50} \mathrm{Zr}_{0.50} \mathrm{O}_{\mathrm{x}}$ was slightly different from the other ceria-zirconia catalysts, as it had an additional reduction peak present at $600{ }^{\circ} \mathrm{C}$, which could be due to a reduction in the presence of phase separated zirconia. The temperature of the surface reduction region remains the same as the non-modified ceria. However, the intensity of the peaks was reduced, indicating the extent of surface ceria reduction was decreased for $\mathrm{Ce}_{0.50} \mathrm{Zr}_{0.50} \mathrm{O}_{\mathrm{x}}$. Zirconia is known to enhance the reduction properties of ceria, this is demonstrated by influencing bulk reduction $[14,15,31]$. The reduction temperature of bulk ceria significantly decreased when zirconia was added to ceria by the mechanochemical carbonate preparation. Consequently, the oxygen mobility of the ceria-zirconia lattice was enhanced, increasing oxygen availability for oxidation catalysis.

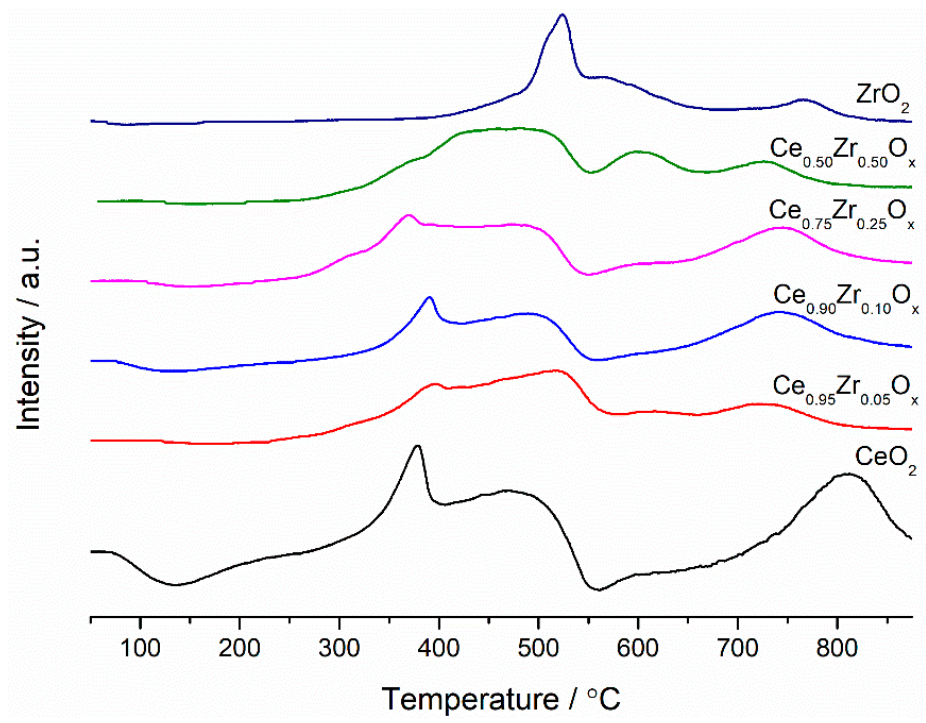

Figure 5. Hydrogen temperature programmed reduction profiles of the ceria-zirconia mixed metal oxide catalysts prepared from carbonate precursors. Analysis conditions: $30 \mathrm{mg}$ sample, $30 \mathrm{~mL} \mathrm{~min}{ }^{-1}$ of $10 \% \mathrm{H}_{2} / \mathrm{Ar}$, heating rate of $15^{\circ} \mathrm{C} \mathrm{min}^{-1}$.

The hydrogen consumption for the reduction in the surface species on the ceria-zirconia catalysts is shown in Table 2. The ceria had the lowest hydrogen consumption, and this value increased 
upon the addition of zirconia. Once the zirconia content of the mixed metal oxide was above $10 \%$, the hydrogen consumption remained unchanged. This effect has also been noted in ceria-zirconia mixed metal oxides prepared using urea coprecipitation [16]. When the surface hydrogen consumption is normalized to surface area, the difference in hydrogen consumption is negated. This suggests the difference in hydrogen consumption of the surface between the samples is due to surface area rather than other factors.

Scanning electron microscopy and energy dispersive x-ray (SEM-EDX) mapping of the mixed ceria-zirconia catalysts is shown in Figure 6. There is a homogenous distribution of cerium and zirconium on the nanometer scale over the $\mathrm{Ce}_{0.95} \mathrm{Zr}_{0.05} \mathrm{O}_{\mathrm{x}}$ and $\mathrm{Ce}_{0.90} \mathrm{Zr}_{0.10} \mathrm{O}_{\mathrm{x}}$ samples. This indicates intimate mixing of the components throughout the catalyst. However, once the zirconia content is increased above $25 \%$, regions enriched with cerium and zirconium are apparent, indicating phase separation between ceria and zirconia. This observation correlates with XRD data, as no distinct bulk zirconia reflections were observed for ceria-zirconia mixed metal oxides with zirconia content below $10 \%$, however, bulk zirconia was present when zirconia content was above $25 \%$.

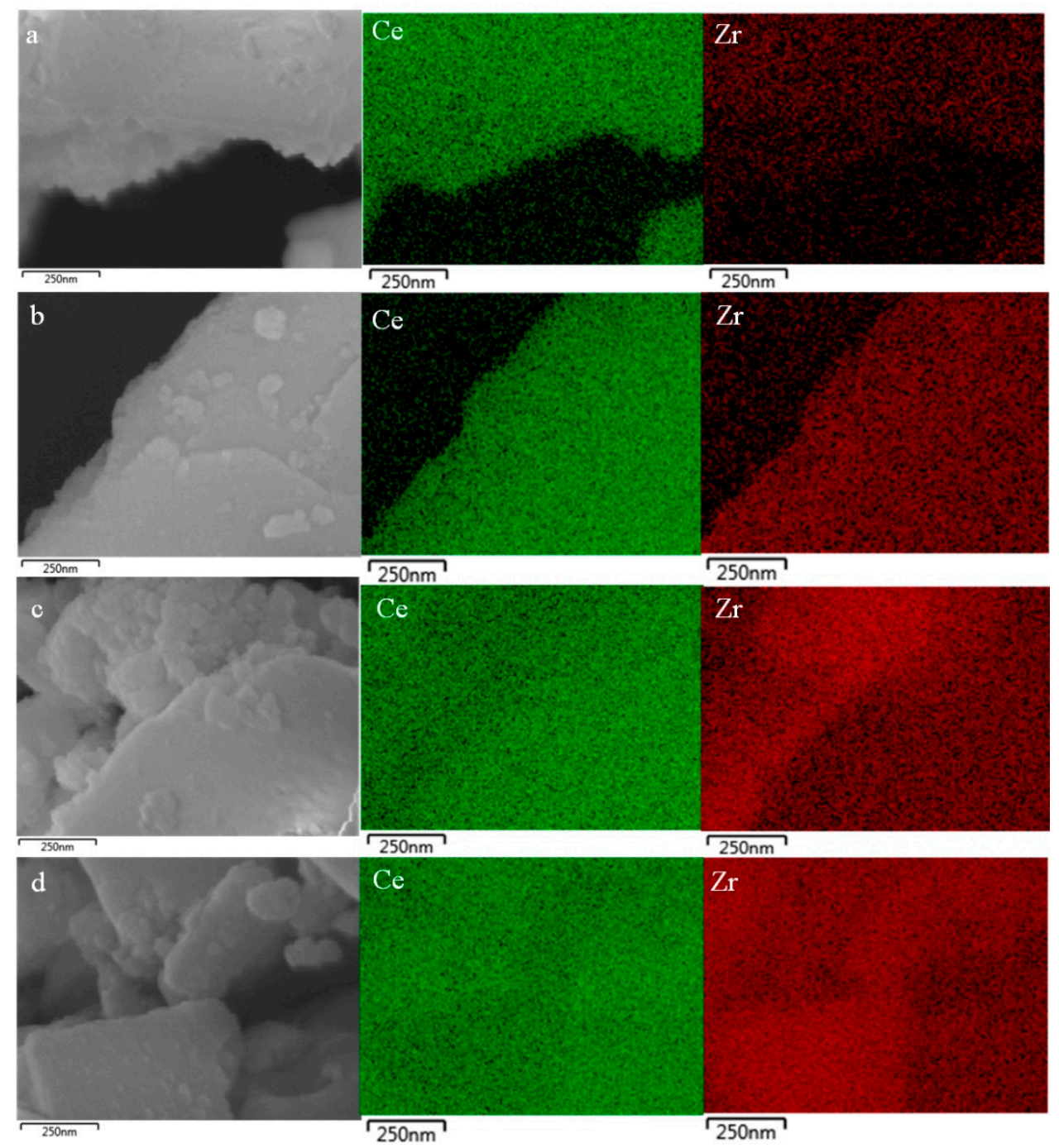

Figure 6. SEM-EDX mapping of (a) $\mathrm{Ce}_{0.95} \mathrm{Zr}_{0.05} \mathrm{O}_{\mathrm{x}}$, (b) $\mathrm{Ce}_{0.90} \mathrm{Zr}_{0.10} \mathrm{O}_{\mathrm{x}}$, (c) $\mathrm{Ce}_{0.75} \mathrm{Zr}_{0.25} \mathrm{O}_{\mathrm{x}}$, and (d) $\mathrm{Ce}_{0.50} \mathrm{Zr}_{0.50} \mathrm{O}_{\mathbf{x}}$ prepared mechanochemically using carbonate precursors. Showing cerium (green) and zirconium (red).

The bulk elemental analysis by EDX for the ceria-zirconia catalysts is shown in Table 3. The ceria sample had no zirconium present in the bulk. This indicates that no contamination from the zirconia 
milling materials occurred during preparation. Elemental analysis of the mixed metal oxides showed that the cerium and zirconium concentrations were close to the nominal values for all mixed metal oxide samples. The $\mathrm{Ce}_{0.50} \mathrm{Zr}_{0.50} \mathrm{O}_{\mathrm{x}}$ sample showed the largest variation in cerium and zirconium ratio, which may be due to the phase separation of the sample, leading to enriched areas of cerium and zirconium, influencing EDX sampling.

The surface composition of the catalysts analyzed by x-ray photoelectron spectroscopy (XPS) is shown in Table 3. No zirconium was identified on the surface of the ceria, confirming that no contamination from the zirconia ball milling material occurred during preparation. Although the bulk EDX analysis showed that the metal ratios were close to the nominal synthesis values expected for the mixed metal oxides, the surface ratios significantly deviated from the bulk ratios. In other studies, ceria-zirconia mixed metal oxide prepared by mechanochemical grinding of chloride precursors showed that a relatively small amount of zirconium was incorporated into the ceria framework. The excess zirconia was deposited on the ceria surface, or formed crystalline zirconia species [23]. In the present study, a similar conclusion was reached for mechanochemical preparation from carbonates, as there was mixed phase formation, evidence of discreet zirconia phases at higher zirconium content, and surface enrichment of zirconium. A general trend showed that the activity of ceria-zirconia mixed metal oxide catalysts decreased as the surface zirconium content increased, and this is consistent with the ceria-zirconia having greater activity than zirconia.

Table 3. EDX and XPS derived elemental concentrations for the ceria-zirconia mixed metal oxides.

\begin{tabular}{ccccccc}
\hline Sample & \multicolumn{2}{c}{$\begin{array}{c}\text { Relative Concentration } \\
\text { from EDX/at \% }\end{array}$} & \multicolumn{2}{c}{$\begin{array}{c}\text { Relative Concentration } \\
\text { from XPS/at\% }\end{array}$} & \multicolumn{2}{c}{$\begin{array}{c}\text { Relative O Species from } \\
\text { XPS/at \% }\end{array}$} \\
& $\mathbf{C e}$ & $\mathbf{Z r}$ & $\mathbf{C e}$ & $\mathbf{Z r}$ & $\mathbf{O}_{\boldsymbol{\alpha}}$ & $\mathbf{O}_{\boldsymbol{\beta}}$ \\
\hline $\mathrm{CeO}_{2}$ & 100 & 0 & 100 & 0 & 54.1 & 45.9 \\
$\mathrm{Ce}_{0.95} \mathrm{Zr}_{0.05} \mathrm{O}_{\mathbf{x}}$ & 94.8 & 5.2 & 77.8 & 22.2 & 44.4 & 55.6 \\
$\mathrm{Ce}_{0.90} \mathrm{Zr}_{0.10} \mathrm{O}_{\mathbf{x}}$ & 89.6 & 10.4 & 71.5 & 28.5 & 48.1 & 51.9 \\
$\mathrm{Ce}_{0.75} \mathrm{Zr}_{0.25} \mathrm{O}_{\mathbf{x}}$ & 76.5 & 23.5 & 53.7 & 46.3 & 48.8 & 51.2 \\
$\mathrm{Ce}_{0.50} \mathrm{Zr}_{0.50} \mathrm{O}_{\mathbf{x}}$ & 55.5 & 44.5 & 41.1 & 58.9 & 53.3 & 46.7 \\
$\mathrm{ZrO}_{2}$ & 0 & 100 & 0 & 100 & - & - \\
\hline
\end{tabular}

The Ce 3d spectral region of the ceria-zirconia catalysts is shown in Figure 7. The ceria only catalyst had the highest intensity peaks, which decreased upon increasing the zirconia content of the mixed metal oxide. $\mathrm{Ce}^{4+}$ was the dominant oxidation state of all the ceria containing samples due to the presence of a large peak at approximately $917 \mathrm{eV}$, which is noted to be characteristic of $\mathrm{Ce}^{4+}$. The presence of $\mathrm{Ce}^{3+}$ can be seen by the asymmetry of the lower binding energy side of the Ce4+ peak around $882.5 \mathrm{eV}$. For all zirconium levels, there was no significant change in the peak shape, suggesting the presence of zirconium does not significantly affect the oxidation state of the ceria in the mixed metal oxides. This was confirmed by the TPR analysis, in which the reduction profiles of the ceria-zirconia mixed metal oxides remained similar regardless of the zirconia content in the mixed metal oxides.

Figure 8 shows the peak fitting for the O 1s XPS signal of the ceria-zirconia mixed metal oxide catalysts. There were three oxygen species present on the surface of the mixed oxide catalysts [43]. The first species assigned to the binding energy just below $530 \mathrm{eV}$ is characteristic of lattice oxygen $\left(\mathrm{O}_{\alpha}\right)$, whilst the species at $531 \mathrm{eV}$ can be assigned to defective oxygen sites $\left(\mathrm{O}_{\beta}\right)$, with the species at $533 \mathrm{eV}$ due to water or some surface carbonate species. All ceria containing catalysts had these species present, and as we consider the $\mathrm{O}_{\beta}$ concentration to be related to the activity, the relative concentration ratios of only lattice oxide and $\mathrm{O}_{\beta}$ are shown in Table 3. The ceria had the lowest relative concentration of $\mathrm{O}_{\beta}$, and this value increased upon the addition of any amount of zirconia. The ceria-zirconia mixed metal oxides containing the lowest amounts of zirconia ( $5 \%$ and $10 \%$ ) had the highest relative amount of defective oxygen species on the surface. 


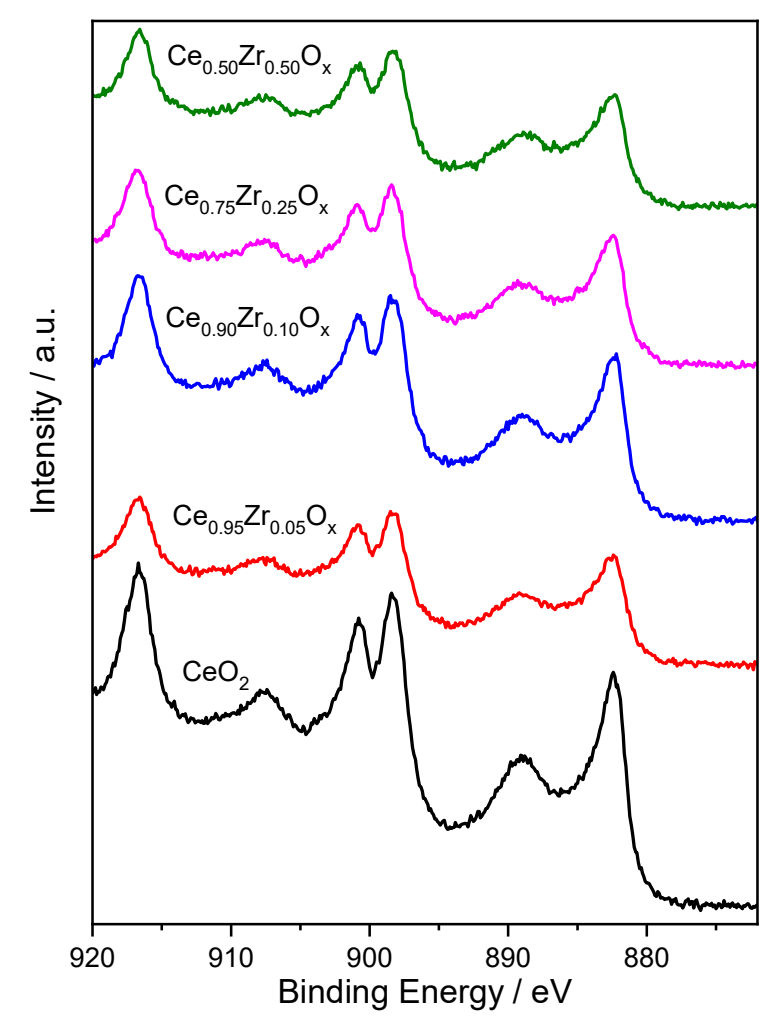

Figure 7. XPS spectra of the Ce 3d peaks for the ceria-zirconia mixed metal oxide catalysts prepared from carbonate precursors.

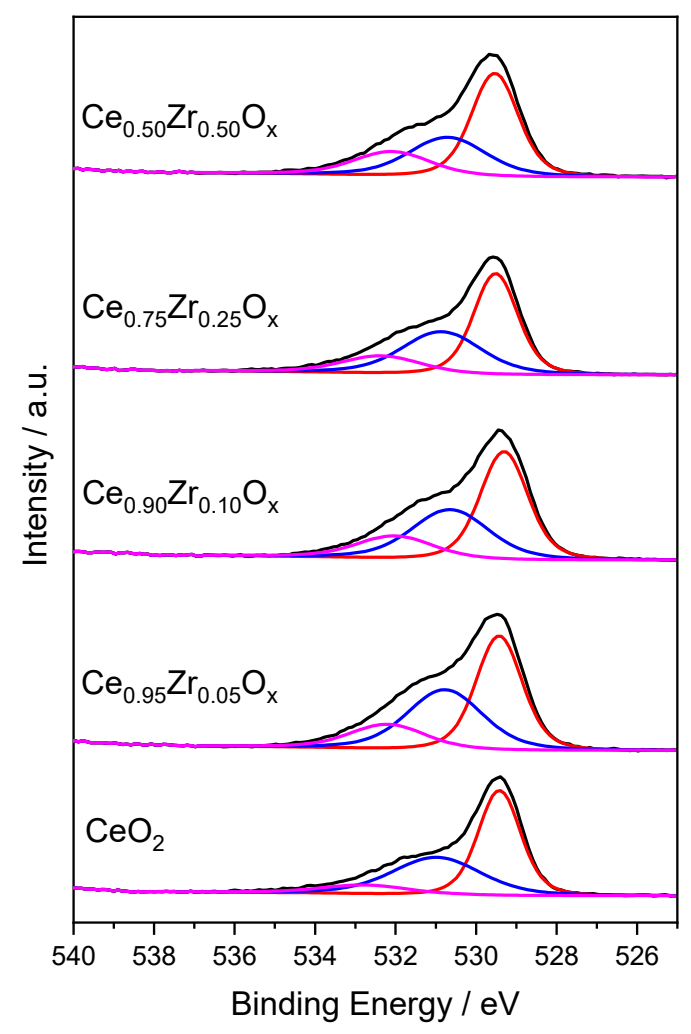

Figure 8. XPS spectra of the $\mathrm{O}$ 1s peaks of the ceria-zirconia mixed metal oxides prepared from carbonate precursors. 
The relationship between the relative concentration of surface $\mathrm{O}_{\beta}$ and the activity for total oxidation of propane and naphthalene is shown in Figure 9. It has been reported previously that the relative concentrations of $\mathrm{O}_{\beta}$ in copper-modified ceria catalysts correlate with its naphthalene total oxidation ability [44]. For both propane [45] and naphthalene [46], the process of catalytic total oxidation occurs via a Mars-van Krevelen mechanism, and the ease and extent of the oxygen removal from the lattice, i.e., its mobility, is key to catalyst activity [47]. These are controlled by surface oxygen species, oxygen vacancies, and other defect sites on the surface of the mixed metal oxide. The strong correlation between surface concentration of $\mathrm{O}_{\beta}$ and the activity for both propane and naphthalene oxidation suggests that the surface defects are the key factor controlling catalyst activity.
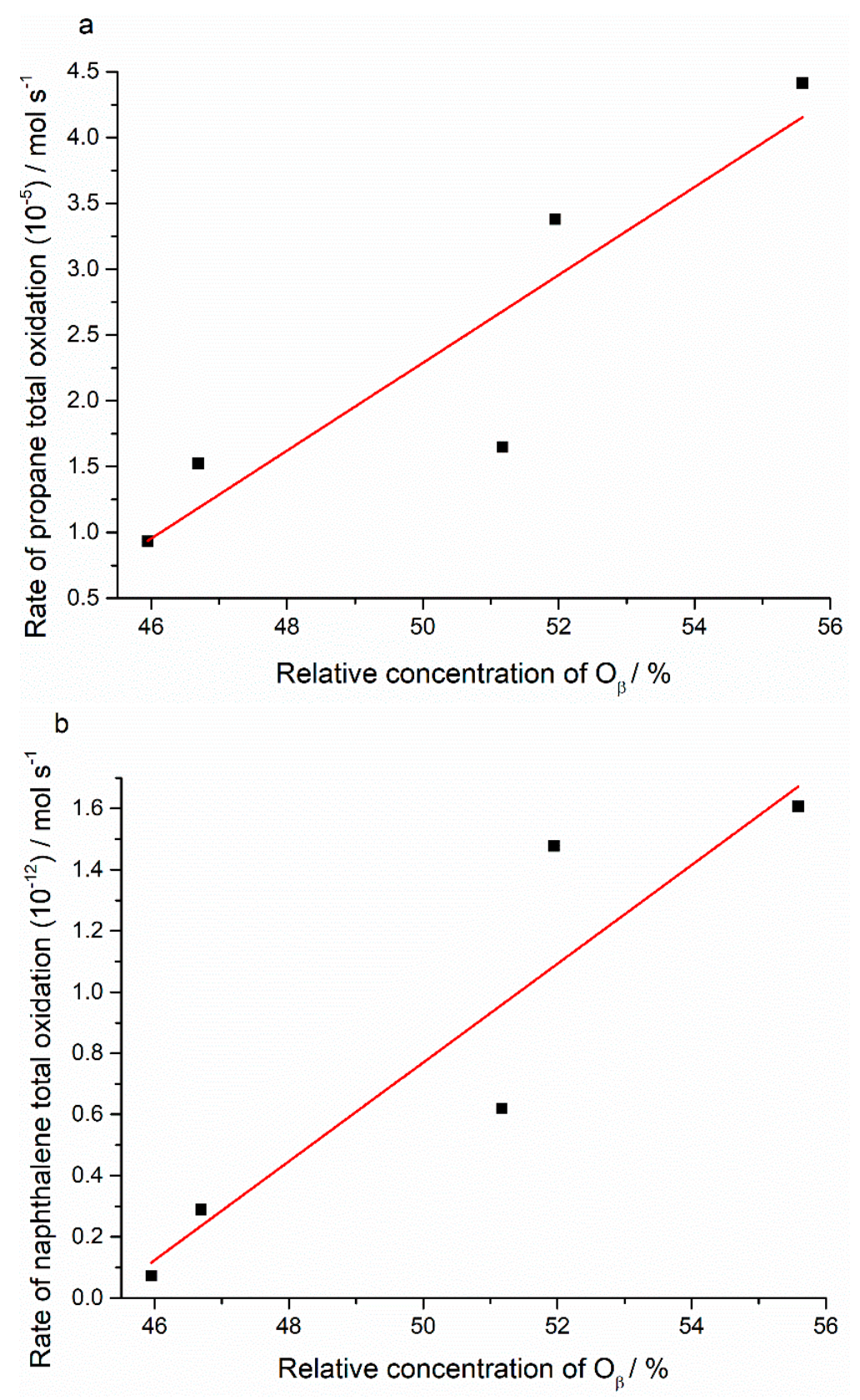

Figure 9. The correlation between the relative surface concentrations of $\mathrm{O}_{\beta}$ measured by XPS and the catalyst activity of ceria-zirconia for total oxidation, (a) propane total oxidation activity at $350{ }^{\circ} \mathrm{C}$, and (b) naphthalene total oxidation activity at $200^{\circ} \mathrm{C}$. 


\section{Materials and Methods}

\subsection{Catalyst Preparation}

A series of mechanochemically prepared ceria-zirconia mixed metal oxides were made using a planetary orbital ball mill (Retsch PM100). The Ce:Zr ratios studied were 100:0, 95:5, 90:10, 75:25, 50:50, and 0:100. Appropriate amounts of $\mathrm{Ce}_{2}\left(\mathrm{CO}_{3}\right)_{3} \cdot 6 \mathrm{H}_{2} \mathrm{O}$ (Sigma-Aldrich 99.9\%, Gillingham, UK) and $\mathrm{Zr}(\mathrm{OH})_{2} \mathrm{CO}_{3} \cdot \mathrm{ZrO}_{2}$ (Sigma-Aldrich 95\%, Gillighma, UK) were weighed to the correct ratios and lightly ground using a pestle and mortar. The mixture was placed into a $\mathrm{ZrO}_{2}$ lined crucible $(10 \mathrm{~cm})$ containing seven $\mathrm{ZrO}_{2}$ balls $(15 \mathrm{~mm}$ ). The carbonates were ground in the ball mill at $200 \mathrm{rpm}$ for $4 \mathrm{~h}$ at room temperature to produce the catalyst precursor. The powdered precursors were calcined under flowing air $\left(400{ }^{\circ} \mathrm{C}, 3 \mathrm{~h}\right.$ (ramp rate $1{ }^{\circ} \mathrm{C} \mathrm{min}^{-1}$ from ambient)) to produce the catalyst.

\subsection{Catalyst Testing}

Catalyst testing was carried out using two continuous flow fixed bed microreactors. In both cases, catalyst samples were placed into $6 \mathrm{~mm}$ o.d. stainless steel tubes and secured between two plugs of quartz wool.

Propane total oxidation was carried out using a $50 \mathrm{~mL} \mathrm{~min}^{-1}$ flow of $5000 \mathrm{vppm}$ propane in air. Catalysts were packed at a constant volume to ensure the gas-hour space velocity (GHSV) was $45,000 \mathrm{~h}^{-1}$. Catalyst activity was measured in the temperature range of $200-600{ }^{\circ} \mathrm{C}$ at $50{ }^{\circ} \mathrm{C}$ intervals. The temperature was controlled by a K-type thermocouple placed in contact with the catalyst bed. The reaction was monitored using online gas chromatography (Agilent 7090B, Stockport, UK) with thermal conductivity detector (TCD) and a flame ionization detector (FID) in series. The TCD was used to analyze $\mathrm{O}_{2}$ and $\mathrm{N}_{2}$, and an FID equipped with a methanizer was used to analyze $\mathrm{CO}_{2}, \mathrm{CO}$, and hydrocarbons. Separation was done on two columns: a Haysep Q (80-100 mesh, $1.8 \mathrm{~m} \times 3.2 \mathrm{~mm})$ and a MolSieve 13 X (80-100 mesh, $2 \mathrm{~m} \times 3.2 \mathrm{~mm})$.

Naphthalene total oxidation was undertaken using $50 \mathrm{~mL} \mathrm{~min}^{-1} 100 \mathrm{vppm}$ naphthalene in $\mathrm{He} / \mathrm{O}_{2}$. Gas phase naphthalene was generated in a thermostatically controlled furnace at $35{ }^{\circ} \mathrm{C}$ under a He flow $\left(40 \mathrm{~mL} \mathrm{~min}^{-1}\right)$, and then $\mathrm{O}_{2}\left(10 \mathrm{~mL} \mathrm{~min}^{-1}\right)$ was added. The total flow was $50 \mathrm{~mL} \mathrm{~min}{ }^{-1}$. The catalyst bed was heated using a clam-shell furnace. Activity was measured over a $100-250{ }^{\circ} \mathrm{C}$ range at $25^{\circ} \mathrm{C}$ intervals. Temperature was controlled by placing a K-type thermocouple in contact with the catalyst bed. The reaction effluent was analyzed using online gas chromatography (Agilent 7090B), with separation achieved using an HP-5 $(30 \mathrm{~m} \times 0.32 \mathrm{~mm} \times 0.25 \mu \mathrm{m})$ and a Haysep Q (80-100 mesh, $3 \mathrm{~m} \times 3.2 \mathrm{~mm}$ ) columns with FID and methanizer-FID detectors.

At each reaction temperature the catalyst was allowed to stabilize for a defined time before analysis of the reaction products was performed. Multiple analyses were carried out to ensure the catalyst was at steady-state, and activity data were obtained by taking the average of three reproducible analyses. Carbon balances for all propane total oxidation activity measurements were $100 \pm 1 \%$.

\subsection{Catalyst Characterisation}

Powder X-ray diffraction patterns were collected using a Panalytical X'Pert diffractometer (Malvern Panalytical, Malvern, UK), equipped with a Cu X-ray source operating at $40 \mathrm{kV}$ and $40 \mathrm{~mA}$. The ICDD standard database was used for phase identification. Crystallite size was estimated using $\mathrm{X}$-ray line broadening by applying the Scherrer equation, comparing the experimental line widths of the four major diffraction peaks against a highly crystalline silicon standard.

Surface area analysis was done using a Quantachrome Quadrasorb Evo Analyser (Quantachrome, Hook, UK). Catalysts were degassed under vacuum for $16 \mathrm{~h}$ at $250^{\circ} \mathrm{C}$ before surface area determination was undertaken. Surface areas were determined from five-point $\mathrm{N}_{2}$ adsorption isotherms measured at $-196^{\circ} \mathrm{C}$. The data was treated using the Brunauer-Emmett-Teller (BET) method.

Laser Raman spectra were obtained using a Renishaw inVia confocal Raman microscope (Renishaw, Gloucestershire, UK) equipped with an argon ion visible green laser. The wavelength of the laser 
used was $514 \mathrm{~nm}$ and spectra were collected in reflective mode using a highly sensitive charge couple device detector.

Temperature programmed reduction was performed using a Quantachrome ChemBET TPD/R/O (Quantachrome, Hook, UK). Catalysts were pre-treated under a flow of He for $1 \mathrm{~h}$ at $120{ }^{\circ} \mathrm{C}$. Reduction profiles were attained by analyzing approximately $30 \mathrm{mg}$ of catalyst under a flow of $10 \% \mathrm{H}_{2} / \mathrm{Ar}\left(30 \mathrm{~mL} \mathrm{~min}^{-1}\right)$, over the temperature range from ambient to $1100^{\circ} \mathrm{C}$, with a heating rate of $15^{\circ} \mathrm{C} \mathrm{min}^{-1}$.

Scanning electron microscopy and electron dispersive X-ray spectroscopy were performed on a Tescan MAIA3 field emission gun scanning electron microscope (Tescan, Cambridge, UK) fitted with an Oxford Instruments X-ray $\mathrm{Max}^{\mathrm{N}} 80$ detector. Samples were loaded onto a carbon tape and the data analyzed using Aztec software.

X-ray photoelectron spectroscopy was carried out using a Thermo Scientific K-Alpha ${ }^{+}$spectrometer (Thermo Fisher Scientific, East Grinstead, UK), equipped with an $\mathrm{Al} \mathrm{K}_{\alpha}$ micro-focused monochromator operating at $72 \mathrm{~W}(6 \mathrm{~mA}, 12 \mathrm{kV})$. Survey and high-resolution scans were recorded at pass energies of $150 \mathrm{eV}$ and $40 \mathrm{eV}$, respectively with a 1 or $0.1 \mathrm{eV}$ step size. Surface charging was neutralized by a combined flux of low energy electrons and Ar ions. Spectra were calibrated against the C (1s) peak at $284.8 \mathrm{eV}$. The resulting data were analyzed using CasaXPS (v2.3.19rev1.11, Casa Software Ltd., Teignmouth, UK), using Scofield sensitivity factors and an energy dependence of -0.6 , after removal of a Shirley background.

\section{Conclusions}

The synthesis of catalyst precursors by mechanochemical preparation using carbonates is a viable route to active mixed ceria-zirconia oxide catalysts for the total oxidation of naphthalene and propane. The formation of mixed ceria-zirconia phases resulted in increased catalyst performance. $\mathrm{Ce}_{0.95} \mathrm{Zr}_{0.05} \mathrm{O}_{\mathrm{x}}$ was found to be the most active catalyst for propane and naphthalene oxidation, which follows similar observations for ceria-zirconia catalysts prepared by other methods. The preparation method led to the formation of single ceria-zirconia solid solutions phases at 10\% zirconia and lower. Once the zirconia content was above $25 \%$, ceria-zirconia and phase segregated zirconia were formed. EDX showed that the bulk concentrations were close to nominal synthesis values. However, the surface showed an increased zirconia concentration, indicating that the surface was not as well mixed as the bulk. The addition of zirconia led to a relative increase in surface oxygen defect species compared to ceria. The increase in these species showed significant correlations with activity for propane and naphthalene oxidation.

Author Contributions: S.H.T. is responsible for conceptualisation and oversight of the research. P.M.S. and J.W.H.B. performed the catalytic studies and catalyst characterisation. D.J.M. performed x-ray photoelectron spectroscopy measurements and data analysis, whilst T.E.D. performed electron microscopy measurements and data analysis. All authors contributed equally to the preparation of the manuscript.

Funding: This research received no external funding.

Acknowledgments: The authors would like to acknowledge financial support from Cardiff University and experimental assistance from the Cardiff University Transmission Electron Microscopy Facility.

Conflicts of Interest: The authors declare no conflict of interest.

\section{References}

1. Duan, J.; Tan, J.; Yang, L.; Wu, S.; Hao, J. Concentration, Sources and Ozone Formation Potential of Volatile Organic Compounds (VOCs) during Ozone Episode in Beijing. Atmos. Res. 2008, 88, 25-35. [CrossRef]

2. Ryerson, T.B.; Trainer, M.; Holloway, J.S.; Parrish, D.D.; Huey, L.G.; Sueper, D.T.; Frost, G.J.; Donnelly, S.G.; Schauffler, S.; Atlas, E.L.; et al. Observations of Ozone Formation in Power Plant Plumes and Implications for Ozone Control Strategies. Science 2001, 292, 719-723. [CrossRef]

3. Gurjar, B.R.; Jain, A.; Sharma, A.; Agarwal, A.; Gupta, P.; Nagpure, A.S.; Lelieveld, J. Human Health Risks in Megacities Due to Air Pollution. Atmos. Environ. 2010, 44, 4606-4613. [CrossRef] 
4. Flagan, R.C.; Seinfield, J.H. Fundamentals of Air Pollution Engineering, 1st ed.; Prentice-Hall Inc.: Upper Saddle River, NJ, USA, 1988; ISBN 0-13-332537-7.

5. Available online: http://www.theglobaleconomy.com/rankings/lpg_consumption/ (accessed on 28 July 2017).

6. Choudhary, V.R.; Deshmukh, G.M.; Mishra, D.P. Kinetics of the Complete Combustion of Dilute Propane and Toluene over Iron-Doped $\mathrm{ZrO}_{2}$ Catalyst. Energy Fuels 2005, 19, 54-63. [CrossRef]

7. Ramadhas, A.S. Alternative Fuels for Transportation, 6th ed.; CRC Press: Boca Raton, FL, USA, 2011.

8. U.S. Environmental Protection Agency. Contaminant Candidate List Regulatory Determination Support Document for Naphthalene. Fed. Regist. 2003, 68, 42898-42906.

9. Heneghan, C.S.; Hutchings, G.J.; Taylor, S.H. Catalysis Volume 17; The Royal Society of Chemistry: London, UK, 2004.

10. Sharma, R.K.; Zhou, B.; Tong, S.; Chuane, K.T.; Tg, A. Catalytic Destruction of Volatile Organic Compounds Using Supported Platinum and Palladium Hydrophobic Catalysts. Ind. Eng. Chem. 1995, 34, 4310-4317. [CrossRef]

11. Menegazzo, F.; Burti, P.; Signoretto, M.; Manzoli, M.; Vankova, S.; Boccuzzi, F.; Pinna, F.; Strukul, G. Effect of the Addition of $\mathrm{Au}$ in Zirconia and Ceria Supported Pd Catalysts for the Direct Synthesis of Hydrogen Peroxide. J. Catal. 2008, 257, 369-381. [CrossRef]

12. Shapovalov, V.; Metiu, H. Catalysis by Doped Oxides: CO Oxidation by $\mathrm{Au}_{\mathrm{x}} \mathrm{Ce}_{1-\mathrm{x}} \mathrm{O}_{2}$. J. Catal. 2007, 245, 205-214. [CrossRef]

13. Zhang, X.; Shi, H.; Xu, B.Q. Comparative Study of $\mathrm{Au} / \mathrm{ZrO}_{2}$ Catalysts in CO Oxidation and 1,3-Butadiene Hydrogenation. Catal. Today 2007, 122, 330-337. [CrossRef]

14. Thammachart, M.; Meeyoo, V.; Risksomboon, T.; Osuwan, S. Catalytic Activity of $\mathrm{CeO}_{2}-\mathrm{ZrO}_{2}$ Mixed Oxide Catalysts Prepared Via Sol-Gel Technique: CO Oxidation. Catal. Today 2001, 68, 53-61. [CrossRef]

15. Bedrane, S.; Descorme, C.; Duprez, D. Investigation of the Oxygen Storage Process on ceria- and Ceria-Zirconia-Supported Catalysts. Catal. Today 2002, 75, 401-405. [CrossRef]

16. Sellick, D.R.; Aranda, A.; García, T.; López, J.M.; Solsona, B.; Mastral, A.M.; Morgan, D.J.; Carley, A.F.; Taylor, S.H. Influence of the Preparation Method on the Activity of Ceria Zirconia Mixed Oxides for Naphthalene Total Oxidation. Appl. Catal. B Environ. 2013, 132, 98-106. [CrossRef]

17. Bampenrat, A.; Meeyoo, V.; Kitiyanan, B.; Rangsunvigit, P.; Rirksomboon, T. Catalytic Oxidation of Naphthalene over $\mathrm{CeO}_{2}-\mathrm{ZrO}_{2}$ Mixed Oxide Catalysts. Catal. Commun. 2008, 9, 2349-2352. [CrossRef]

18. Zamar, F.; Trovarelli, A.; De Leitenburg, C.; Dolcetti, G. $\mathrm{CeO}_{2}$-Based Solid Solutions with the Fluorite Structure as Novel and Effective Catalysts for Methane Combustion. J. Chem. Soc. Chem. Commun. 1995, 2, 965. [CrossRef]

19. Omidvarborna, H.; Kumar, A.; Kim, D.S. Recent Studies on Soot Modeling for Diesel Combustion. Renew. Sustain. Energy Rev. 2015, 48, 635-647. [CrossRef]

20. Anastas, P.T.; Warner, J.C. Green Chemistry Theory and Practice; Oxford University Press: New York, NY, USA, 1998.

21. Ralphs, K.; Hardacre, C.; James, S.L. Application of Heterogeneous Catalysts Prepared by Mechanochemical Synthesis. Chem. Soc. Rev. 2013, 42, 7701-7718. [CrossRef]

22. Suda, A.; Kandori, T.; Ukyo, Y.; Sobukawa, H.; Sugiura, M. Room Temperature Synthesis Solid Phase of Ceria-Zirconia Reaction Solid Solution by. J. Ceram. Soc. Japan 2000, 108, 473-477. [CrossRef]

23. Carbajal-Ramos, I.A.; Andrade-Gamboa, J.; Gennari, F.C. Nanostructured $\mathrm{Ce}_{1-\mathrm{x}} \mathrm{ZrxO}_{2}$ Solid Solutions Produced by Mechanochemical Processing. Mater. Chem. Phys. 2013, 137, 1073-1080. [CrossRef]

24. Devaiah, D.; Reddy, L.H.; Park, S.-E.; Reddy, B.M. Ceria-Zirconia Mixed Oxides: Synthetic Methods and Applications. Catal. Rev. 2018, 60, 177-277. [CrossRef]

25. Shah, P.M.; Day, A.N.; Davies, T.E.; Morgan, D.J.; Taylor, S.H. Mechanochemical Preparation of Ceria-Zirconia Catalysts for the Total Oxidation of Propane and Naphthalene Volatile Organic Compounds. Appl. Catal. B Environ. 2019, 253, 331-340. [CrossRef]

26. Hasan, M.A.; Zaki, M.I.; Pasupulety, L. IR Investigation of the Oxidation of Propane and Likely C3 and C2 Products over Group IVB Metal Oxide Catalysts. J. Phys. Chem. B 2002, 106, 12747-12756. [CrossRef]

27. Teng, M.; Luo, L.; Yang, X. Synthesis of Mesoporous $\mathrm{Ce}_{1-\mathrm{x}} \mathrm{Zr}_{\mathrm{x}} \mathrm{O}_{2}(\mathrm{x}=0.2-0.5)$ and Catalytic Properties of $\mathrm{CuO}$ Based Catalysts. Microporous Mesoporous Mater. 2009, 119, 158-164. [CrossRef]

28. Chen, L.; Mashimo, T.; Omurzak, E.; Okudera, H.; Iwamoto, C.; Yoshiasa, A. Pure Tetragonal $\mathrm{ZrO}_{2}$ Nanoparticles Synthesized by Pulsed Plasma in Liquid. J. Phys. Chem. C 2011, 115, 9370-9375. [CrossRef] 
29. Damyanova, S.; Pawelec, B.; Arishtirova, K.; Huerta, M.V.M.; Fierro, J.L.G. Study of the Surface and Redox Properties of Ceria-Zirconia Oxides. Appl. Catal. A Gen. 2008, 337, 86-96. [CrossRef]

30. Pauling, L. Atomic Radii and Interatomic Distances in Metals. J. Am. Chem. Soc. 1947, 69, 542-553. [CrossRef]

31. Vlaic, G.; Di Monte, R.; Fornasiero, P.; Fonda, E.; Kašpar, J.; Graziani, M. Redox Property-Local Structure Relationships in the Rh-Loaded $\mathrm{CeO}_{2}-\mathrm{ZrO}_{2}$ Mixed Oxides. J. Catal. 1999, 182, 378-389. [CrossRef]

32. Chen, A.; Zhou, Y.; Ta, N.; Li, Y.; Shen, W. Redox Properties and Catalytic Performance of Ceria-Zirconia Nanorods. Catal. Sci. Technol. 2015, 5, 4184-4192. [CrossRef]

33. Trovarelli, A.; Fornasiero, P. Catalysis by Ceria and Related Materials, 2nd ed.; Imperial College Press: London, UK, 2013.

34. Katz, G. X-Ray Diffraction Powder Pattern of Metastable Cubic $\mathrm{ZrO}_{2}$. J. Am. Ceram. Soc. 1971, 54, 531. [CrossRef]

35. Bozo, C.; Guilhaume, N.; Garbowski, E.; Primet, M. Combustion of Methane on $\mathrm{CeO}_{2}-\mathrm{ZrO}_{2}$ Based Catalysts. Catal. Today 2000, 59, 33-45. [CrossRef]

36. Hirano, A.; Suda, A. Oxygen Storage Capacity, Specific Surface Area, and Pore-Size Distribution of Ceria-Zirconia Solid Solutions Directly Formed by Thermal Hydrolysis. J. Am. Ceram. Soc. 2003, 11, 2209-2211. [CrossRef]

37. Liang, C.; Qiu, J.; Li, Z.; Li, C. Synthesis of Nanostructured Ceria, Zirconia and Ceria-Zirconia Solid Solutions Using an Ultrahigh Surface Area Carbon Material as a Template. Nanotechnology 2004, 15, 843-847. [CrossRef]

38. Garcia, T.; Solsona, B.; Taylor, S.H. Nano-Crystalline Ceria Catalysts for the Abatement of Polycyclic Aromatic Hydrocarbons. Catal. Lett. 2005, 105, 183-189. [CrossRef]

39. Spanier, J.E.; Robinson, R.D.; Zhang, F.; Chan, S.-W.; Herman, I.P. Size-Dependent Properties of $\mathrm{CeO}_{2-\mathrm{y}}$ Nanoparticles as Studied by Raman Scattering. Phys. Rev. B 2001, 64, 245407. [CrossRef]

40. Kosacki, I.; Suzuki, T.; Anderson, H.U.; Colomban, P. Raman Scattering and Lattice Defects in Nanocrystalline $\mathrm{CeO}_{2}$ Thin Films. Solid State Ion. 2002, 149, 99-105. [CrossRef]

41. Pigos, J.M.; Brooks, C.J.; Jacobs, G.; Davis, B.H. Low Temperature Water-Gas Shift: Characterization of Pt-Based $\mathrm{ZrO}_{2}$ Catalyst Promoted with $\mathrm{Na}$ Discovered by Combinatorial Methods. Appl. Catal. A Gen. 2007, 319, 47-57. [CrossRef]

42. Maity, S.; Rana, M.; Srinivas, B.; Bej, S.; Murali Dhar, G.; Prasada Rao, T.S. Characterization and Evaluation of $\mathrm{ZrO}_{2}$ Supported Hydrotreating Catalysts. J. Mol. Catal. A Chem. 2000, 153, 121-127. [CrossRef]

43. Galtayries, A.; Sporken, R.; Riga, J.; Blanchard, G.; Caudano, R. XPS Comparative Study of Ceria/Zirconia Mixed Oxides: Powders and Thin Film Characterisation. J. Electron Spectrosc. Rel. Phenom. 1998, 88-91, 951-956. [CrossRef]

44. Aranda, A.; Aylón, E.; Solsona, B.; Murillo, R.; Mastral, A.M.; Sellick, D.R.; Agouram, S.; García, T.; Taylor, S.H. High Activity Mesoporous Copper Doped Cerium Oxide Catalysts for the Total Oxidation of Polyaromatic Hydrocarbon Pollutants. Chem. Commun. 2012, 48, 4704-4706. [CrossRef]

45. Balcaen, V.; Roelant, R.; Poelman, H.; Poelman, D.; Marin, G.B. TAP Study on the Active Oxygen Species in the Total Oxidation of Propane over a CuO-CeO $\mathrm{C}_{2} / \gamma-\mathrm{Al}_{2} \mathrm{O}_{3}$ catalyst. Catal. Today 2010, 157, 49-54. [CrossRef]

46. Ntainjua, E.; Taylor, S.H. The Catalytic Total Oxidation of Polycyclic Aromatic Hydrocarbons. Top. Catal. 2009, 52, 528-541. [CrossRef]

47. Aranda, A.; Agouram, S.; López, J.M.; Mastral, A.M.; Sellick, D.R.; Solsona, B.; Taylor, S.H.; García, T. Oxygen Defects: The Key Parameter Controlling the Activity and Selectivity of Mesoporous Copper-Doped Ceria for the Total Oxidation of Naphthalene. Appl. Catal. B Environ. 2012, 127, 77-88. [CrossRef]

(C) 2019 by the authors. Licensee MDPI, Basel, Switzerland. This article is an open access article distributed under the terms and conditions of the Creative Commons Attribution (CC BY) license (http://creativecommons.org/licenses/by/4.0/). 